\title{
Perilaku Vandalisme Penyedia Jaringan Telekomunikasi (Studi Kasus PT TELKOM Akses Area Bekasi oleh Karyawan Unit Maintenance URC)
}

\author{
Astuty Pohan ${ }^{1)}$, Mia Meilina ${ }^{2)}$, Abdul Asman ${ }^{3)}$ \\ Program Studi Ilmu Komunikasi, Universitas Bhayangkara Jakarta Raya, Jakarta, Indonesia \\ Corresponding Author: astuty.pohan@dsn.ubharajaya.ac.id,+6285691327520
}

\begin{abstract}
Abstrak - Saat ini perkembangan teknologi komunikasi yang semakin pesat menuntut perusahaan telekomunikasi di Indonesia dapat bersaing dengan kompetitor lainnya untuk memberikan pelayanan terbaik terhadap konsumen. Saat ini banyak provider layanan telekomunikasi banyak yang bermunculan sehingga persaingan semakin menguat dan kompetitif, karena setiap perusahaan berupaya membangun kekuatan masing-masing, bahkan persaingan tersebut membuat organisasi perusahaan secara totalitas harus profesional dalam mengelola perusahaan dengan terus meningkatkan kekuatan secara menyeluruh. Penelitian ini bertujuan untuk mengetahui faktor dan bentuk perilaku vandalisme karyawan PT Telkom Akses Unit Maintenance URC. Bentuk penelitian ini adalah penelitian Kualitatif dengan studi kasus. Paradigma penelitian yang digunakan dalam penelitian ini adalah Postpositivisme. Teknik pengumpulan data yang dilakukan melalui observasi, wawancara dan dokumentasi. Hasil dari penelitian ini adalah adanya faktor dan bentuk perilaku vandalisme karyawan PT Telkom Akses Unit Maintenance URC area Bekasi. Faktor perilaku vandalisme berawal dari adanya aktifitas komunikasi efektif dalam grup whatsapp muncul perintah untuk melakukan vandalisme. Faktor dan bentuk vandalisme karyawan PT Telkom Akses unit maintenance Area Bekasi dalam melakukan vandalisme adalah fakor personal dan faktor situasional sedangkan bentuk perilaku vandalisme berupa tactical, vindicate dan malicious vandalism. Copyright (O2019 Department of industrial engineering. All rights reserved.
\end{abstract}

Kata Kunci: Vandalisme, Faktor Personal, Faktor Situasional, Komunikasi Efektif.

\section{Pendahuluan}

PT Telkom Akses merupakan anak perusahaan dari PT Telkom Indonesia Tbk (Telkom), dimana sahamnya sepenuhnya dimiliki oleh PT Telkom Indonesia Tbk. PT Telkom Akses bergerak dalam bisnis penyediaan layanan konstruksi mulai dari pembangunan jaringan fiber optik dan pengelolaan infrastruktur jaringan yaitu melakukan perawatan dan perbaikan jaringan telekomunikasi. Lahirnya PT Telkom Akses sebagai anak perusahaan Telkom Group yang berupaya untuk menghadirkan jaringan telekomunikasi berbasis koneksi internet berkualitas dan terjangkau untuk meningkatkan kualitas sumber daya manusia Indonesia agar mampu bersaing di tingkat dunia. Sebagai anak perusahaan Telkom Group, PT Telkom Akses berusaha mewujudkan impian untuk tetap mempertahankan Telkom Indonesia sebagai provider telekomunikasi nomor satu di Indonesia.

Sebagai anak perusahaan besar PT Telkom Akses tentu saja sudah selayaknya mampu menciptakan sumber daya manusia yang baik demi mempertahankan citra besar PT Telkom Indonesia Tbk. sendiri dengan memberikan pelatihan kerja serta motivasi lebih agar karyawan dapat melaksanakan tugasnya dengan baik sehingga mendapatkan prestasi yang tinggi dari perusahaan maupun atasannya langsung, sehingga banyak karyawan yang selalu menuruti apapun perintah dari atasan untuk mencapai prestasi individu maupun kelompok meskipun perintah yang diberikan atasan beresiko dan menyimpang dari aturan. Reward dan rierforcement merupakan faktor penting dalam belajar. Tujuan psikologi adalah meramal mengontrol tingkah laku. Pada teori ini guru memberi penghargaan hadiah atau nilai tinggi sehingga anak akan lebih rajin [1].

Saat ini perkembangan teknologi komunikasi yang semakin pesat menuntut perusahaan telekomunikasi di Indonesia dapat bersaing dengan kompetitor lainnya untuk memberikan pelayanan terbaik terhadap konsumen. Saat ini banyak provider layanan telekomunikasi banyak yang bermunculan sehingga persaingan semakin menguat dan kompetitif, karena setiap perusahaan berupaya membangun kekuatan masing-masing, bahkan persaingan tersebut membuat organisasi perusahaan secara totalitas harus profesional dalam mengelola perusahaan dengan terus meningkatkan kekuatan secara menyeluruh. Sangat disayangkan dari beberapa provider persaingan tersebut berjalan secara tidak sehat, karena masih ada segelintir orang yang berani melakukan aksi vandalisme terhadap provider lain. 
Vandalisme adalah penodaan atau perusakan yang menarik perhatian, dan dilakukan sebagai ekspresi kemarahan, kreativitas, atau keduanya. Seiring dengan berjalannya waktu vandalisme digolongkan menjadi sebuah tindakan kriminal [2]. Bahkan pemerintah Indonesia memberlakukan hukuman penjara selama tiga sampai enam bulan dan denda sesuai dengan kerusakan yang diakibatkan. Pemerintah Indonesia sendiri juga telah membuat peraturan tentang vandalisme yaitu pada Bab XXVII KUHP tentang "Penghancuran atau Perusakan Barang", tepatnya di Pasal 406-412 KUHP. Kenyataannya meskipun di Indonesia sudah memiliki payung hukum yang berlaku masih banyak orang melakukan vandalisme dengan melakukan penghancuran atau perusakan barang orang lain.

Tindakan vandalisme yang menarik perhatian peneliti adalah tindakan vandalisme yang dilakukan oleh karyawan PT Telkom Akses unit maintenance URC bekasi khususnya. Perkembangan teknologi jaringan telekomunikasi yang pesat menimbulkan persaingan dengan provider lain. Vandalisme dilakukan oleh karyawan unit Maintenance URC bekasi dengan cara melakukan pemotongan kabel jaringan telekomunikasi milik provider lain sehingga dapat menimbulkan gangguan massal yang dialami oleh provider lain. Keunikan yang lain karena para pelaku vandalisme tersebut mengetahui bahwa tindakan vandalisme yang mereka lakukan adalah tindakan yang melanggar peraturan, tetapi mereka tetap saja melakukan aksi tersebut dikarenakan adanya perintah dari atasan.

Berdasarkan hasil observasi dan wawancara kepada karyawan PT Telkom Akses unit Maintenance URC area Bekasi yang melakukan vandalisme, mereka melakukan vandalisme pada siang dan malam hari ketika mereka sedang bekerja di lapangan. Dalam aksinya tersebut mereka tidak melakukannya secara terjadwal namun tetap terorganisir. Tidak ada waktu khusus untuk melakukan aksi vandalisme karena setiap melakukan aksinya mereka hanya akan melakukannya jika memang adanya kabel provider lain yang dapat menghambat pekerjaan mereka seperti adanya kabel provider lain yang "menumpang" di tiang milik Telkom ataupun memang sebelumnya kabel milik Telkom sudah di potong terlebih dahulu oleh provider lain tanpa sebab yang pasti, maka para pelaku vandalisme tidak ragu dalam melakukan aksinya.

Perilaku vandalisme yang dilakukan oleh karyawan PT Telkom Akses pun adanya perintah dari atasan mereka dengan beralasan aksi balas dendam terhadap pemotongan kabel yang sudah lebih dahulu dilakukan oleh provider lain terhadap kabel milik PT Telkom Indonesia Tbk., sehingga adanya motif dalam aksi vandalisme yang dilakukan oleh karyawan PT Telkom Akses. Hal tersebut tentu saja tidak seharusnya dibenarkan karena dengan adanya perintah tersebut para karyawan yang melakukan aksi vandalisme merasa terlindungi dan membenarkan apa yang sudah mereka lakukan, bahkan perilaku vandalisme menjadi kebiasaan dilakukan jika memang di dasari dengan alasan yang kuat. Motif menunjuk hubungan sistematik antara suatu respon atau suatu himpunan respon dengan keadaan dorongan tertentu [3].

Motif sebagai implus atau dorongan yang memberikan energi pada tindakan manusia sepanjang lintasan kognitif/perilaku ke arah pemuasan kebutuhan. Motif tidak harus dipersepsikan secara sadar. la lebih merupakan suatu "keadaan perasaan". Motif adalah segala daya mendorong seseorang untuk melakukan sesuatu [4].

Melihat kasus yang telah diuraikan di atas, peneliti merasa pentingnya mengkaji lebih lanjut tentang motif dan bentuk perilaku vandalisme yang merupakan konsep dari psikologi komunikasi yang dilakukan oleh karyawan PT Telkom Akses unit Maintenance URC Area Bekasi.

Tujuan dari penelitian ini adalah untuk mengetahui faktor-faktor yang mempengaruhi mengapa karyawan PT Telkom Akses Unit Maintenance URC melakukan aksi vandalisme dan bagaimana bentuk perilaku vandalisme karyawan PT Telkom Akses Unit Maintenance URC.

\section{Landasan Teori}

\subsection{Psikologi Komunikasi}

Komunikasi sangat esensial buat pertumbuhan kepribadian manusia. Ahli-ahli ilmu sosial telah berkalikali mengungkapkan bahwa kurangnya komunikasi akan menghambat perkembangan kepribadian [6]. Di dalam sebuah referensi diungkapkan bahwa "the most important agency through which the child learns to be human is communication, verbal also nonverbal." Kedua, komunikasi sangat erat kaitannya dengan perilaku dan pengalaman kesadaran manusia. Tidak mengherankan, bahwa komunikasi selalu menarik perhatian peneliti psikologi [7].

Dilihat dari sejarah perkembangannya, komunikasi memang dibesarkan oleh para peneliti psikologi. Tiga di antara empat orang bapak ilmu komunikasi yang disebut Wilbur Schramm adalah sarjana-sarjana psikologi. Kurt lewin adalah ahli psikologi dinamika kelompok. la memperoleh gelar doktornya dalam asuhan Koffka, Kohler, dan Wertheimer, tokoh-tokoh psikologi Gestalt. Paul lazarsfeld, pendiri ilmu komunikasi lainnya, adalah psikolog yang banyak dipengaruhi Sigmund freud, bapak psikoanalisis. Carl I. Hovland, adalah seorang yang dididik dalam psikologi, dan selama hidupnya memilih karir psikologi, dia pernah menjadi asisten clark hull, tokoh psikologi aliran behaviorisme. Menarik sekali bahwa aliran besar dalam psikologi diwakili oleh para peletak dasar ilmu komunikasi [7].

Komunikasi begitu esensial dalam masyarakat sehingga setiap orang yang belajar tentang manusia mesti sesekali waktu menolehnya, komunikasi telah ditelaah dari berbagai segi: antropologi, biologi, 
ekonomi, sosiologi, linguistic, psikologi, politik, matematik, engineering, neurofisiologi, filsafat dan sebagainya. Psikologi juga meneliti kesadaran dan pengalaman manusia. Psikologi terutama mengarahkan perhatiannya pada perilaku manusia dan mencoba menyimpulkan proses kesadaran yang menyebabkan terjadinya perilaku itu. Bila sosiologi melihat pada interaksi sosial, filsafat pada hubungan manusia dengan realitas lainnya, psikologi pada perilaku individu komunikan [7].

Kepribadian terbentuk sepanjang hidup kita. Selama itu pula komunikasi menjadi penting untuk pertumbuhan pribadi kita. Melalui komunikasi kita menemukan diri kita, mengembangkan konsep diri, dan menetapkan hubungan kita dengan dunia sekitar kita. Hubungan kita dengan orang lain menentukan kualitas hidup kita. Bila orang lain tidak memahami gagasan anda, bila pesan anda menjengkelkan mereka, bila anda tidak berhasil mengatasi masalah pelik karena orang lain menentang pendapat anda dan tidak mau membantu anda, bila semakin sering anda berkomunikasi semakin jauh jarak anda dengan mereka. Bila anda selalu gagal untuk mendorong orang lain bertindak, anda telah gagal dalam komunikasi. Komunikasi anda tidak efektif. Bagaimana tanda-tanda komunikasi yang efektif? Komunikasi yang efektif menurut Stewart L. Tubss dan Sylvia Moss paling tidak menimbulkan lima hal : Pengertian, kesenangan, pengaruh pada sikap, hubungan yang makin baik, dan tindakan [7].

Berdasarkan uraian di atas dapat disimpulkan bahwa psikologi dengan komunikasi sangat berkaitan erat satu sama lain tiga dari empat bapak ilmu komunikasi merupakan orang psikologi. Komunikasi akan menjadi efektif apabila pesan yang dikirim dapat diterima oleh seseorang dan dapat merubah perilaku serta mampu menggerakan seseorang dari stimuli yang diterima dari pengirim pesan.

\subsection{Motif}

Secara etimologis, motif dalam bahasa inggrisnya motive, berasal dari kata motion, yang berarti "gerakan" atau "sesuatu yang bergerak". Jadi, istilah "motif" berkaitan erat dengan "gerak", yaitu gerakan yang dilakukan oleh manusia, atau disebut juga perbuatan atau tingkah laku. Pada dasarnya motif merupakan pengertian dari penggerak. Alasan-alasan atau dorongan-dorongan dalam diri manusia yang menyebabkan manusia itu sendiri berbuat sesuatu. Semua tingkah laku manusia pada hakikatnya mempunyai motif tersendiri.

Sherif misalnya menyebut motif sebagai suatu istilah generik yang meliputi semua faktor internal yang mengarah pada berbagai jenis perilaku yang bertujuan, semua pengaruh internal, seperti needs atau kebutuhan yang berasal dari fungsi organisme, dorongan dan keinginan, aspirasi dan selera sosial, yang bersumber dari fungsi-fungsi tersebut. Giddens mengartikan motif sebagai implus atau dorongan yang memberikan energi pada tindakan manusia sepanjang lintasan kognitif/perilaku ke arah pemuasan kebutuhan. Menurut Giddens, motif tidak harus dipersepsikan secara sadar. la lebih merupakan suatu "keadaan perasaan". Secara singkat, Nasution M.A. menjelaskan bahwa motif adalah segala daya mendorong seseorang untuk melakukan sesuatu [8].

Berdasarkan uraian di atas dapat disimpulkan bahwa motif adalah dorongan yang berasal dari dalam diri manusia yang bergerak untuk berbuat sesuatu. Hal tersebut berkaitan dengan penelitian peneliti bahwa seorang yang melakukan vandalisme terdorong karena adanya motif di dalam dirinya sendiri.

\subsection{Vandalisme}

Vandalisme merupakan kata yang berasal dari kata vandal atau vandalus, yang mengacu pada nama suatu suku pada masa Jerman purba yang menempati wilayah sebelah selatan Baltik antara Vistula dan Oder. Di abad keempat dan kelima Masehi suku Vandal ini mengembangkan wilayahnya sampai menjangkau Spanyol dan Afrika Selatan. Pada tahun 455 masehi banyak suku Vandal datang memasuki kota Roma dan menghancurkan karya seni dan sastra Romawi yang terdapat pada waktu itu. Dari perilaku suku Vandal tersebut, vandal kemudian diberi makna seseorang yang dengan sengaja menghancurkan atau merusak sesuatu yang indah-indah. Tidak jelas apa motifnya yang dilakukan oleh suku vandal tersebut dalam merusak karya yang indah tersebut, sangat mungkin merupakan keirihatian terhadap prestasi yang dihasilkan oleh pihak lain.

Menurut George T Felkness vandalisme merupakan sebuah tindak kejahatan yang bertujuan untuk merusak barang-barang. Aksi perusakan tersebut meliputi perusakan fasilitas umum maupun fasilitas pribadi, coretan slogan pada tembok ditempat umum, perusakan terhadap mesin-mesin dan banyak lagi bentuk dari aksi perusakan tersebut. Dalam Kamus Besar Bahasa Indonesia (KBBI) menjelaskan bahwa vandalisme adalah suatu kegiatan merusak dan menghancurkan hasil karya seni dan barang berharga lainnya (keindahan alam, dsb) atau perusakan secara kasar dan ganas. Senada dengan apa yang dikatakan Goldstein, vandalisme adalah tindakan yang bertujuan untuk merusak benda-benda milik orang lain. Kim \& Bruchman mengungkapkan bahwa vandalisme adalah penodaan atau perusakan yang menarik perhatian, dan dilakukan sebagai ekspresi kemarahan, kreativitas, atau keduanya [8].

Dari pengertian vandalisme di atas dapat menyimpulkan bahwa vandalisme adalah tindakan yang bertujuan untuk merusak benda-benda atau karya seni milik orang lain. dalam penelitian ini vandalisme yang dilakukan oleh karyawan PT Telkom Akses unit Maintenance URC adalah memotong kabel 
telekomunikasi milik provider lain sehingga menimbulkan kerusakan.

\section{Metodologi}

\subsection{Metode Penelitian}

Metode penelitian adalah serangkaian hukum, aturan, dan tata cara tertentu yang diatur dan ditentukan kaidah ilmiah dalam menyelenggarakan suatu penelitian dalam koridor keilmuan tertentu yang hasilnya dapat dipertanggung jawabkan secara ilmiah [9].

Metode penelitian adalah cara-cara ilmiah untuk mendapatkan data yang valid, dengan tujuan dapat ditemukan, dikembangkan dan dibuktikan, suatu pengetahuan tertentu sehingga pada gilirannya dapat digunakan untuk memahami, memecahkan dan mengantisipasi masalah [10].

Pertanyaan-pertanyaan dalam mencari dalil umum akan mudah terjawab, seperti seberapa jauh, mengapa begitu, apakah benar, dan sebagainya [9].

Metodologi ialah ilmu tentang kerangka kerja untuk melaksanakan penelitian yang bersistem: sekumpulan pengaturan, kegiatan dan prosedur yang digunakan oleh pelaku suatu disiplin ilmu; studi atau analisis teoritis mengenai suatu cara/metode atau cabang ilmu logika yang berkaitan dengan prinsip umum pembentukan pengetahuan (Knowledge) [10].

Disini peneliti melakukan metode penelitian deskriptif, menggunakan pendekatan kualitatif dengan menggunakan metode studi kasus, selain itu peneliti juga akan memaparkan mengenai teknik pengumpulan data key informan dan informan, analisis data, serta tempat dan waktu penelitian.

\subsubsection{Paradigma Penelitian}

Paradigma adalah kumpulan longgar dari sejumlah asumsi yang dipegang bersama, konsep atau proposisi yang mengarahkan cara berpikir dan penelitian [9]. Paradigma sebagai seperangkat aturan (tertulis atau tidak tertulis) yang melakukan dua hal: (1) hal itu membangun atau mendefinisikan batas-batas. Dan (2) hal ini menceritakan kepada anda bagaimana seharusnya melakukan sesuatu didalam batas-batas itu agar berhasil [10].

Dalam istilah kualitatif paradigma merupakan paling penting bagi sebuah penelitian. Dikatakan paradigma adalah sistem dasar yang menyangkut keyakinan atau pandangan yang mendasar terhadap dunia objek yang diteliti yang merupakan panduan bagi peneliti [9].

Metode penelitian kualitatif adalah metode penelitian yang berlandaskan pada filsafat postpostivisme digunakan untuk meneliti kondisi objek yang alamiah, dimana peneliti adalah instrument kunci, teknik pengumpulan data dilakukan secara triangulasi (gabungan), untuk dapat menjadi instrument peneliti harus memiliki bekal teori dan wawancara yang luas sehingga mampu untuk dapat bertanya, menganalisis, memotret, dan mengkonstruksi situasi sosial yang di teliti [10].

Maka dari itu penelitian ini menggunakan paradigma post-positivisme, dari penjelasan di atas peneliti dapat menyimpulkan bahwa paradigm penelitian yaitu konsep atau proposisi yang mengarahkan cara berfikir dan penelitian disini menggunakan paradigma postpostivisme karena proses ini membahas mengenai sebab-akibat dimana pada penelitian ini peneliti memperhatikan perilaku vandalisme yang dilakukan oleh karyawan PT Telkom Akses terhadap provider kabel jaringan telekomunikasi lain.

\subsubsection{Pendekatan Penelitian}

Peneliti merumuskan pendekatan penelitian dengan cara menjabarkan secara rinci mengenai latar belakang masalah. Pendekatan penelitian ini adalah pendekatan penelitian kualitatif. Penelitian kualitatif adalah penelitian yang memiliki tingkat kritisme yang lebih dalam semua proses penelitian [9].

Tujuan utama penelitian kualitatif yakni untuk memahami fenomena atau gejala sosial dengan cara memberikan pemaparan berupa penggambaran yang jelas tentang fenomena atau gejala sosial tersebut dalam bentuk rangkaian kata yang pada akhirnya akan menghasilkan sebuah teori [10].

Menurut Bogdan dan Taylor, kualitatif adalah prosedur penelitian yang menghasilkan data deskriptif berupa ucapan atau tulisan dan perilaku yang dapat diamati dari orang-orang itu sendiri menunjukan setting dan individu-individu dalam setting itu keseluruhan, individu dalam batasan yang sangat holistic [9].

Thomas $\mathrm{R}$ Lindlof menyatakan bahwa penelitian kualitatif berupaya memelihara bentuk-bentuk dan muatan-muatan perilaku manusia tersebut, bukan dengan cara matematis atau transformasi formal lainnya [9].

\subsubsection{Jenis Penelitian}

Dalam menentukan metode penelitian maka tahap selanjutnya adalah memilih metode penelitian, untuk lebih memfokuskan dari penelitian ini, jenis metode yang digunakan adalah metode studi kasus. Penelitian studi kasus adalah studi yang mengeksplorasi suatu masalah dengan batasan terperinci, memiliki pengambilan data yang mendalam, dan menyertakan berbagai sumber informasi. Penelitian ini dibatasi oleh waktu dan tempat, dan kasus yang di pelajari berupa program, peristiwa, aktivitas, atau individu [9].

Menurut Yin studi kasus adalah suatu inquiry empiris yang mendalam fenomena dalam konteks kehidupan nyata, ketika batas antara fenomena dan konteks tak tampak dengan tegas [9].

Studi kasus adalah suatu metode untuk memahami individu yang dilakukan secara integrative dan komprehensif agar diperoleh pemahaman yang 
mendalam tetang individu tersebut beserta masalah yang dihadapinya dengan tujuan masalahnya dapat terselesaikan dan memperoleh perkembangan diri yang baik [10].

\subsubsection{Key Informan dan Informan}

1. Key informan (Narasumber Kunci)

Key informan adalah seseorang yang tidak hanya bisa memberi keterangan tentang sesuatu kepada peneliti, tetapi juga bisa memberikan saran tentang sumber bukti yang mendukung serta menciptakan sesuatu terhadap sumber yang bersangkutan [9].

Key Informan atau narasumber dalam penelitian ini ditentukan dengan memilih orang-orang tertentu karena dapat dianggap pas untuk mewakili tingkat signifikan narasumber pada penelitian. Key Informan (informan kunci) merupakan mereka yang mengetahui dan memiliki berbagai informasi pokok yang diperlukan dalam penelitian [10].

2. Informan (Narasumber)

Informan harus mengalami langsung situasi atau kejadian yang berkaitan dengan topik penelitian. Informan dapat menggambarkan kembali fenomena yang telah dialaminya, terutama dalam sifat alamiah dan maknanya, hasilnya akan diperoleh data yang alami dan reflektif menggambarkan keadaan yang sesungguhnya. Informan bersedia untuk diwawancarai dan direkam aktivitasnya selama penelitian berlangsung [9]. Informan adalah seseorang atau anggota kelompok yang diharapkan mempunyai informasi [10].

\subsection{Teknik Pengumpulan Data}

Teknik pengumpulan data merupakan cara yang dilakukan peneliti untuk mengungkap suatu atau menjaring informan dari responden sesuai penelitian [9].

\subsubsection{Wawancara}

Wawancara adalah percakapan dengan maksud tertentu dimana dilakukan oleh dua pihak yaitu pewawancara (interviewer) yang mengajukan pertanyaan dan terwawancara (interview) yang memberikan jawaban atas pertanyaan tersebut yang tujuannya menggali dan mendapatkan informasi untuk suatu tujuan tertentu [9]

Wawancara terbagi menjadi 2 tipe, yaitu:

1. Wawancara mendalam (in depth interview), dimana peneliti terlibat langsung secara mendalam dengan kehidupan subyek yang diteliti dan tanya jawab yang dilakukan tanpa menggunakan pedoman yang disiapkan sebelumnya serta dilakukan berkali-kali.

2. Wawancara terarah (guide interview) dimana peneliti menanyakan kepada subyek yang diteliti berupa pertanyaan-pertanyaan yang menggunakan pedoman yang di siapkan sebelumnya. Pewawancara terikat dengan pertayaan yang telah disiapkan sebelumnya sehingga suasana menjadi kurang santai [10].

\subsubsection{Observasi}

Observasi adalah kemampuan seseorang untuk menggunakan pengamatannya melalui hasil kerja panca indra mata serta dibantu dengan panca indra lainnya. Ada beberapa bentuk observasi, yakni:

1. Observasi Partisipan

Metode pengumpulan data yang digunakan untuk menghimpun data penelitian melalui pengamatan dan penginderaan dimana peneliti terlibat dalam keseharian informan.

2. Observasi Tidak Terstruktur

Pengamatan yang dilakukan tanpa menggunakan pedoman observasi sehingga peneliti mengembangkan pengamatannya berdasarkan perkembangan yang terjadi dilapangan.

3. Observasi Kelompok

Pengamatan yang dilakukan oleh sekelompok tim peneliti terhadap sebuah isu yang diangkat menjadi objek penelitian [9].

Berdasarkan macam-macam observasi di atas maka peneliti menetukan jenis observasi, yaitu menggunakan observasi tidak terstuktur dimana peneliti akan mengembangkan pengamatannya berdasarkan perkembangan yang terjadi di lapangan.

\subsubsection{Dokumentasi}

Metode pengumpulan data kualitatif yang sejumlah besar data dan fakta tersimpan dalam bentuk komunikasi.

\subsection{Teknik Analisa Data}

Dalam penelitian kualitatif, data diperoleh dari berbagai sumber, dengan menggunakan teknik pengumpulan data yang bermacam-macam, dan dilakukan secara terus menerus sampai datanya jenuh [10]. Bogdan menyatakan bahwa [9]:

"Data analysis is the process of systematically searching and arranging the interview transcripts, fieldnotes, and other materials that you accumulate to increase your own understanding of them and to enable you to present what you have discovered to others."

Analisis merupakan proses mencari dan menyusun secara sistematis data yang diperoleh dari hasil wawancara, catatan lapangan, dan bahan-bahan lain, sehingga dapat mudah dipahami, dan temuannya dapat diinformasikan kepada orang lain. Analisis data dilakukan dengan mengorganisasikan data, menjabarkannya ke dalam unit-unit, melakukan sintesa, menyusun ke dalam pola, memilih mana yang penting dan yang akan dipelajari, dan membuat kesimpulan yang dapat diceritakan kepada orang lain $[10,11]$.

Peneliti menggunakan analisis data Model Miles dan Huberman. Analisis data dalam penelitian kualitatif, dilakukan pada saat pengumpulan data berlangsung, dan setelah selesai pengumpulan data dalam periode 
tertentu. Miles and Huberman mengemukakan bahwa aktivitas dalam analisis data kualitatif dilakukan secara interaktif dan berlangsung secara terus menerus sampai tuntas, sehingga datanya sudah jenuh. Aktivitas dalam analisis data, yaitu data reduction, data display, dan conclusion drawing/verification [10].

\subsection{Keabsahan Data}

Menetapkan keabsahan (trustworthines) data diperlukan teknik pemeriksaan. Pelaksanaan teknik pemeriksaan didasarkan atas sejumlah kriteria tertentu. Ada empat kriteria yang digunakan yaitu, derajat kepercayaan (creadibillity), keteralihan (transferabillity), kebergantungan (depandabillity), dan kepastian (confirmabillity) [9].

Keabsahan data menggunakan model triangulasi dalam teknik pengumpulan data dengan teknik pemeriksaan keabsahan data yang memanfaatkan sesuatu yang lain. Peneliti melakukan perbandingan antara hasil pengamatan dengan hasil wawancara. Model Triangulasi diartikan sebagai teknik pengumpulan data yang bersifat menggabungkan dari berbagai teknik pengumpulan data dan sumber data yang telah ada. Bila peneliti melakukan pengumpulan data dengan triangulasi, maka sebenarnya peneliti mengumpulkan data yang sekaligus menguji kredibilitas data, yaitu mengecek kredibilitas data dengan berbagai teknik pengumpulan data dan berbagai sumber data.

\section{Hasil dan Pembahasan}

\subsection{Faktor-Faktor yang mempengaruhi karyawan melakukan vandalisme}

Berdasarkan hasil temuan di lapangan faktor vandalisme karyawan PT Telkom Akses unit Maintenance URC bermula dari terlebih dahulunya kabel jaringan milik Telkom di vandalisme oleh oknum provider lain, sehingga teknisi yang menemukan vandalisme tersebut melaporkan kepada atasannya, Perusahaan besar seperti Telkom akses memiliki cara komunikasi yang efektif dengan memanfaatkan media sosial whatsapp group untuk berkomunikasi langsung dengan karyawan lainnya dimana membuat grup terdiri dari satu bagian ditambah dengan orang-orang yang memiliki jabatan di perusahaan itu group whatssapp ini juga dimanfaatkan untuk memantau setiap kendala pekerjaan yang ada. Seperti yang dikatakan oleh Fisher menyebut empat ciri pendekatan psikologi pada komunikasi : penerimaan stimuli secara indrawi (Sensory reception of stimuli), proses yang mengentarai stimulus dan respons (Internal mediation of stimuli), prediksi respon (prediction of response) dan peneguhan respon (reinforcement responses). Adanya laporan tentang terjadinya vandalisme (Sensory reception of stimuli) teknisi melaporkan hal tersebut dalam sebuah grup whatsapp sebagai (Internal mediation of stimuli) kemudian adanya respon dari berbagai pihak pejabat yang berada di dalam grup tersebut yang dapat menimbulkan (Prediction of responses) dari laporan kasus tersebut untuk melakukan aksi balas dendam dengan melakukan hal yang serupa (Reinforcement responses) [7].

Berdasarkan hasil wawancara yang didapat bahwa adanya faktor situasional yang mendorong para teknisi melakukan vandalisme, adanya iklim organisasi yang menjadi ramai merespon kejadian tersebut, struktur organisasi yang peranan atasannya melakukan perintah kepada bawahannya untuk melakukan aksi balas dendam vandalisme, dan stimuli pendorong dari orang lain yang berasal dari berbagai pihak sehingga teknisi berani melakukan aksi vandalisme tersebut.Teknisi mau tidak mau melakukan vandalisme karena merupakan perintah dari atasan nya langsung. Motif vandalisme yang dilakukan yaitu dorongan dari perintah atasan termasuk dalam faktor situasional (stimuli yang mendorong dan meneguhkan perilaku) untuk melakukan pemotongan (vandalisme) kembali terhadap provider lain karena memang sebelumnya pihak lain telah melakukan vandalisme terhadap kabel milik Telkom, alasan lain mengapa pihak Telkom memberikan intruksi untuk melakukan vandalisme hal yang serupa kepada provider lain dengan harapan mendapatkan efek jera saat di wawancarai.

\subsection{Bentuk Perilaku Vandalisme karyawan PT Telkom Akses}

Vandalisme yang saat ini sering terjadi, berbagai cara semua provider berlomba-lomba untuk menarik minat masyarakat untuk menggunakan poduknya, tidak hanya melalui promosi dan iklan namun secara teknis dilapangan kini sering ditemukan perusakan jaringan oleh beberapa oknum yang dilakukan oleh provider lain terhadap kabel milik Telkom. Tentu saja persaingan menjadi tidak sehat karena adanya kasus vandalisme ini.

George T Felkness vandalisme merupakan sebuah tindak kejahatan yang bertujuan untuk merusak barangbarang. Aksi perusakan tersebut meliputi perusakan fasilitas umum maupun fasilitas pribadi, coretan slogan pada tembok ditempat umum, perusakan terhadap mesin-mesin dan banyak lagi bentuk dari aksi perusakan tersebut.

Pihak Telkom sering menemukan perusakan yang dilakukan secara sengaja oleh oknum provider lain untuk merusak jaringan milik Telkom dengan cara memotong dengan cutter sehingga teknisi dari Telkom sulit untuk menemukan kerusakan yang terjadi berada di titik yang sudah ada dan perusakan tersebut bertujuan untuk balas dendam, jadi aksi vandalisme ini bertujuan bukan untuk mendapatkan suatu barang, namun semata-mata hanya bertujuan untuk membalas dendam atau biasa disebut Vindicate vandalism. Faktor situasional pun menjadi alasan SA melakukan vandalisme di lapangan banyak hal teknis yang mendorong vandalisme terjadi 
dilapangan, banyaknya pembangunan underspec membuat provider dilapangan saling sikut.

Tentu saja hal ini tidak dapat dibiarkan secara terus menerus karena persaingan layanan telekomunikasi akan menjadi tidak sehat, provider lain tanpa ragu melakukan vandalisme terhadap kabel milik Telkom karena mereka menyadari bahwa layanan yang mereka miliki tidak sebaik dan selengkap layanan yang diberikan PT Telkom Indonesia kepada masyarakat sehingga mereka melakukan berbagai macam cara agar pelanggan milik Telkom pindah layanan kepada produk mereka.

\section{Kesimpulan}

Berdasarkan hasil penelitian yang dilakukan dapat ditarik kesimpulan bahwa penyebab motif perilaku vandalisme karyawan PT Telkom Akses unit Maintenance URC Bekasi didasari oleh dua faktor. Pertama ada faktor personal yaitu adanya motif sosiogenetis untuk keinginan mendapat respon, pengakuan dan rasa aman. Selain itu, juga karena adanya emosi dari dalam diri, dan adanya rasa ingin membalas atas vandalisme yang sudah dilakukan oleh provider lain kepada kabel milik Telkom yang membuat pekerjaan mereka semakin menumpuk.

Kedua, Faktor situasional, yaitu suasana lingkup organisasi yang memaksa para bawahan melakukan vandalisme. Lalu, adanya stimuli pendorong dari atasan mengintruksikan bawahan nya untuk melakukan vandalisme. Selain itu, situasi yang ada dilapangan dimana banyaknya pembangunan underspec yang tidak sesuai spesifikasi pembangunan serta banyaknya kabel provider lain yang menumpang ke tiang milik Telkom provider lain sehingga atasan mengintruksikan untuk melakukan vandalisme terhadap kabel provider lain yang berada di tiang milik Telkom.

Sementara, bentuk-bentuk Vandalisme yang dilakukan karyawan PT Telkom Akses unit Maintenance URC Bekasi antara lain : vindicate vandalism, tactical vandalism dan malicious vandalism.

\section{Daftar Pustaka}

[1] Daryanto, \& Rahardjo, M. (2016). Teori Komunikasi. Yogyakarta: Gava Media.

[2] Muhammad, A. (2007). Komunikasi Organisasi. Jakarta: PT Budi Aksara.

[3] Pace, \& Faules. (2013). Komunikasi Organisasi. Bandung: Remaja Rosdakarya.

[4] Anggono, F.R. (2014). Perilaku Vandalisme Pada Remaja di Kabupaten Kulon Progo. Skripsi. Yogyakarta: Fakultas IImu Pendidikan.

[5] Rohim, S. (2016). Teori Komunikasi: Perspektif, Ragam, dan Aplikasi. Jakarta: PT Rineka Cipta.

[6] Bajari, A. (2015). Metode Penelitian Komunikasi. Bandung: Simbiosa Rekatama Media.

[7] Rakhmat, J. (2007). Psikologi Komunikasi. Bandung: Remaja Rosdakarya.

[8] Sobur, A. (2016). Psikologi Umum. Bandung: Pustaka Setia.

[9] Bungin, B. (2007). Penelitian Kualitatif. Jakarta: Prenada Media Grup.

[10] Walgito,Bimo. (2004). Psikologi Sosial Suatu Penghantar. Yogyakarta: Andi.

[11] Effendy, O.U. (2009). Ilmu Komunikasi Teori Dan Praktek. Bandung: Remaja Rosdakarya. 